\title{
Article \\ Nitrate Capture Investigation in Plasma-Activated Water and Its Antifungal Effect on Cryptococcus pseudolongus Cells
}

\author{
Geon Joon Lee ${ }^{1, *}$, Pradeep Lamichhane ${ }^{1}\left(\mathbb{D}\right.$, Seong Jae Ahn ${ }^{2}$, Seong Hwan Kim ${ }^{2, *} \mathbb{C}$, Manesh Ashok Yewale ${ }^{1}$, \\ Choe Earn Choong ${ }^{3}$, , Min Jang ${ }^{3}$ and Eun Ha Choi ${ }^{1, *(1)}$ \\ 1 Department of Electrical and Biological Physics, Plasma Bioscience Research Center, Kwangwoon University, \\ Seoul 01897, Korea; theprodip@gmail.com (P.L.); maneshphd@gmail.com (M.A.Y.) \\ 2 Department of Microbiology, Institute of Biodiversity, Dankook University, Cheonan 31116, Korea; \\ asj0710@naver.com \\ 3 Department of Environmental Engineering, Plasma Bioscience Research Center, Kwangwoon University, \\ Seoul 01897, Korea; cce_@live.com (C.E.C.); minjang@kw.ac.kr (M.J.) \\ * Correspondence: gilee@kw.ac.kr (G.J.L.); piceae@dankook.ac.kr (S.H.K.); ehchoi@kw.ac.kr (E.H.C.); \\ Tel.: +82-2-940-8619 (G.J.L.); +82-41-550-3454 (S.H.K.); +82-2-940-5014 (E.H.C.)
}

check for

updates

Citation: Lee, G.J.; Lamichhane, P.; Ahn, S.J.; Kim, S.H.; Yewale, M.A.; Choong, C.E.; Jang, M.; Choi, E.H. Nitrate Capture Investigation in Plasma-Activated Water and Its Antifungal Effect on Cryptococcus pseudolongus Cells. Int. J. Mol. Sci. 2021, 22, 12773. https://doi.org/ 10.3390/ijms222312773

Academic Editor: Istvan Simon

Received: 9 November 2021

Accepted: 23 November 2021

Published: 26 November 2021

Publisher's Note: MDPI stays neutral with regard to jurisdictional claims in published maps and institutional affiliations.

Copyright: (c) 2021 by the authors. Licensee MDPI, Basel, Switzerland. This article is an open access article distributed under the terms and conditions of the Creative Commons Attribution (CC BY) license (https:/ / creativecommons.org/licenses/by/ $4.0 /)$.

\begin{abstract}
This research investigated the capture of nitrate by magnesium ions in plasma-activated water (PAW) and its antifungal effect on the cell viability of the newly emerged mushroom pathogen Cryptococcus pseudolongus. Optical emission spectra of the plasma jet exhibited several emission bands attributable to plasma-generated reactive oxygen and nitrogen species. The plasma was injected directly into deionized water (DW) with and without an immersed magnesium block. Plasma treatment of DW produced acidic PAW. However, plasma-activated magnesium water (PA-Mg-W) tended to be neutralized due to the reduction in plasma-generated hydrogen ions by electrons released from the zero-valent magnesium. Optical absorption and Raman spectra confirmed that nitrate ions were the dominant reactive species in the PAW and PA-Mg-W. Nitrate had a concentrationdependent antifungal effect on the tested fungal cells. We observed that the free nitrate content could be controlled to be lower in the PA-Mg-W than in the PAW due to the formation of nitrate salts by the magnesium ions. Although both the PAW and PA-Mg-W had antifungal effects on C. pseudolongus, their effectiveness differed, with cell viability higher in the PA-Mg-W than in the PAW. This study demonstrates that the antifungal effect of PAW could be manipulated using nitrate capture. The wide use of plasma therapy for problematic fungus control is challenging because fungi have rigid cell wall structures in different fungal groups.
\end{abstract}

Keywords: plasma-activated water; nitrate capture; Raman spectroscopy; Cryptococcus pseudolongus; cell viability

\section{Introduction}

Recently, the effects of nonthermal atmospheric-pressure plasma on fungi, bacteria, and cancer cells have attracted considerable attention. An atmospheric-pressure plasma jet and dielectric-barrier-discharge plasma have been used to remove microorganisms, inactivate cells, increase plant growth, and treat cancer [1-10]. Plasma can generate reactive oxygen and nitrogen species (RONS). Interactions between plasma radicals and water molecules can produce additional reactive species [1,2] that might also be detrimental to fungi and bacteria. RONS-containing water produced by plasma treatment is called plasma-activated water (PAW) [1,2]. PAW is formed by the extraordinary exchange of energy and matter from plasma to water. Since the emergence of plasma medicine and plasma chemistry, PAW has attracted considerable interest for various applications in biological and medical science as well as in the water, agriculture, and food industries [1,2]. The mechanism of fungal spore inactivation by PAW is of particular interest because PAW can kill a larger volume of fungi than a direct plasma jet can [11,12]. To make PAW a 
practical tool, we need not only a fundamental understanding of its antifungal mechanism but also methods for handling the RONS in PAW in field applications. Generally, PAW becomes acidic because nitric acid forms from the plasma-induced RONS. When zerovalent magnesium $(\mathrm{ZVM})$ is added to the water that is then treated with a plasma jet, the nitrate ions combine with the plasma-induced magnesium ions $\left(\mathrm{Mg}^{2+}\right)$. Electrons released from ZVM reduce the plasma-generated hydrogen ions into hydrogen atoms. The magnesium and nitrate ions exist in equilibrium with nitrate salt. The formation of nitrate salt raises the $\mathrm{pH}$ of the PAW and reduces the level of free nitrate ions. Consequently, it might be possible to use $\mathrm{Mg}^{2+}$ ions to control the level of nitrate in PAW. Lamichhane et al. demonstrated nitrogen fixation by metal ions produced in PAW using an atmosphericpressure nitrogen plasma jet [13] and investigated the possibility of using nitrogen fixation for plant growth [14]. But no systematic study has performed the manipulation of nitrate ions in PAW generated using an atmospheric-pressure Ar plasma jet. It is beneficial to study the capture of nitrate ions in PAW by magnesium ions. Because using PAW in biological applications requires it to be safe and controlled, the development of an effective method to control the nitrate content has great merit in practical applications of PAW.

This study was performed to examine the magnesium ion-induced nitrate capture in PAW and its antifungal effect on the Cryptococcus pseudolongus. To our knowledge, this is the first report in which PAW exhibits an antifungal effect on a Basidiomycota fungus. This fungus has newly emerged as a mushroom pathogen that causes brown rot disease in shiitake [15]. In general, Cryptococcus is a genus of fungi that grow in culture as yeasts. A few species in the Cryptococcus genus cause a disease called cryptococcosis, which is a potentially fatal fungal infection of mainly the lungs and brain in humans [16]. To achieve our research aim, we measured the physicochemical properties of deionized water (DW) and $\mathrm{Mg}$ water treated with a plasma jet (PAW and PA-Mg-W, respectively), and we studied the capture of nitrate in PAW by plasma-induced $\mathrm{Mg}^{2+}$ ions. Next, we examined the effects of PAW and PA-Mg-W treatments on C. pseudolongus cells, and compared the viability of these PAW (PA-Mg-W)-treated cells with that of fungal cells treated by reference free nitrate (nitrate salt). Finally, we described variations in the viability of $C$. pseudolongus cells using the physicochemical properties of PAW and PA-Mg-W.

\section{Results and Discussion}

\subsection{Electrical Characteristics of Atmospheric-Pressure Ar Plasma Discharge}

Figure 1a shows typical current and voltage waveforms of the AC-driven plasma discharge. Several positive current peaks appear in the rising region of the applied voltage, and they result in the accumulation of charges inside a quartz tube. The measured discharge currents were a few tens of milliamperes with durations of a few tens of nanoseconds. During the plasma discharge, the reversed voltage changed the polarity of the accumulated charge. The corresponding charge (Q)-voltage (V) Lissajous plot is shown in Figure $1 \mathrm{~b}$. The Q-V plot becomes a closed loop, and its area gives the total energy dissipated in one cycle $[17,18]$. By fixing the area of the Lissajous plot to a constant value, the plasma treatments of both DW and $\mathrm{Mg}-\mathrm{W}$ were performed under the same discharge power of $5.5 \mathrm{~W}$ [19]. This power corresponds to the energy per cycle of $169 \mu \mathrm{J}$. 


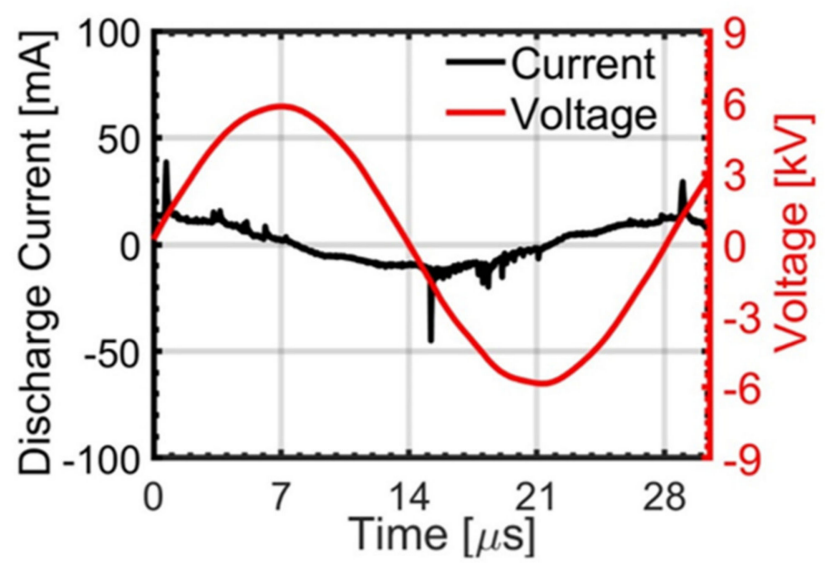

(a)

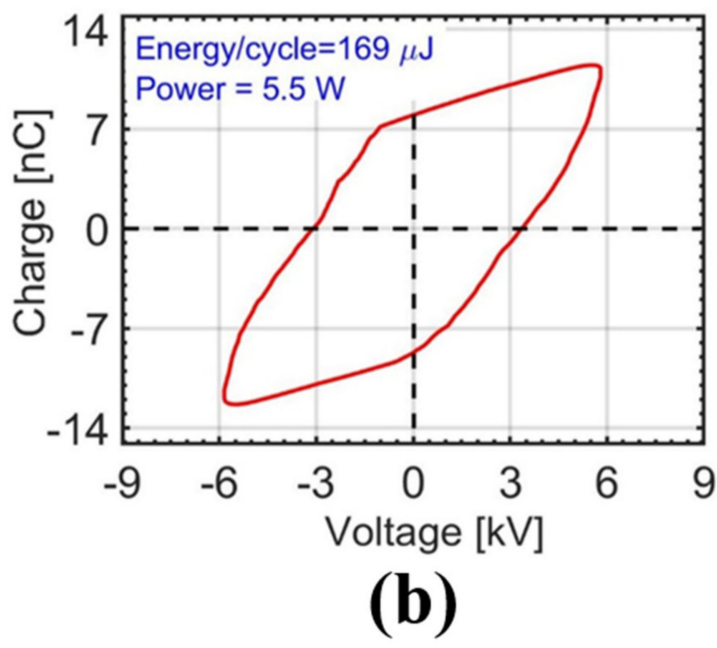

Figure 1. (a) Typical current and voltage profiles of the plasma discharge and (b) Lissajous plot corresponding to the plasma discharge.

\subsection{Analyses of Reactive Oxygen and Nitrogen Species Produced in Plasma Plume and Plasma-Activated Mg Water}

To investigate the reactive species in the plasma jet, optical emission spectroscopy (OES) was used to measure the plasma plume at the end of the quartz tube and at the end of the plasma plume (a position $15 \mathrm{~mm}$ below the nozzle of the quartz tube). As shown in Figure 2a, the OES of the plasma plume at the end of the quartz tube mainly contained various reactive oxygen species (ROS), such as $\mathrm{OH}$ radicals and atomic oxygen. The emission lines of Ar were observed in the wavelength range of 690-925 $\mathrm{nm}$ because Ar served as the working gas, and our plasma device operated at atmospheric pressure $[20,21]$. The emission at $777 \mathrm{~nm}$ was produced by the $\left(2 s^{2} 2 p^{3}\left({ }^{4} S^{0}\right) 3 s \rightarrow 2 s^{2} 2 p^{3}\left({ }^{4} s^{0}\right) 3 p\right)$ transition of atomic oxygen [22,23]. The emission at $308 \mathrm{~nm}$ was generated by the $A^{2} \Sigma=X^{2} \Pi$ transition of excited $\mathrm{OH}$ [24-27]. When oxygen molecules receive sufficient numbers of electrons via the plasma, they can be transformed into reactive oxygen intermediates $(\mathrm{OH}$, $\mathrm{O}_{2}^{-}$and $\mathrm{H}_{2} \mathrm{O}_{2}$ ) through the $\mathrm{O}_{2}$-reduction pathway [28,29]. Meanwhile, the OES at the end of the plasma plume showed various reactive nitrogen species (RNS) attributable to prominent molecular nitrogen lines of $\mathrm{NO}_{\gamma}[200-280 \mathrm{~nm}]$, the nitrogen second positive system [311-380 nm, $\mathrm{N}_{2}\left(C^{3} \Pi_{g} \rightarrow B^{3} \Pi_{g}\right)$ transition)], and the first negative system [390-410 nm, $\mathrm{N}_{2}^{+}\left(B^{2} \Pi_{u}^{+} \rightarrow X^{2} \Pi_{u}^{+}\right)$transition)] [25-27]. To confirm the plasma-induced RNS, we measured the spatial distribution of $\mathrm{NO}_{2}$ below the end of the quartz tube. The gas phase $\mathrm{NO}_{2}$ measurements were performed for the plasma jet propagating under ambient air without water. The longitudinal and transverse spatial distributions of $\mathrm{NO}_{2}$ are shown in Figure $2 b$. In the figure, the vertical distance represents the axial distance away from the end of the quartz tube along the propagation direction of plasma jet. The horizontal distance represents the radial distance away from the center of the plasma plume in the transverse plane perpendicular to the propagation direction of plasma jet. In the horizontal distribution, the negative sign represents the opposite side of the positive sign. In the PAW and PA-Mg-W experiments, the plasma jet is injected directly into water. The gas phase $\mathrm{NO}_{2}$ formed in the spatial region between the end of the quartz tube and the water surface dissolved into water. The $\mathrm{NO}_{2}$ distribution reveals that RNS were dominant at the end of the plume, whereas ROS were dominant at the end of the quartz tube. 


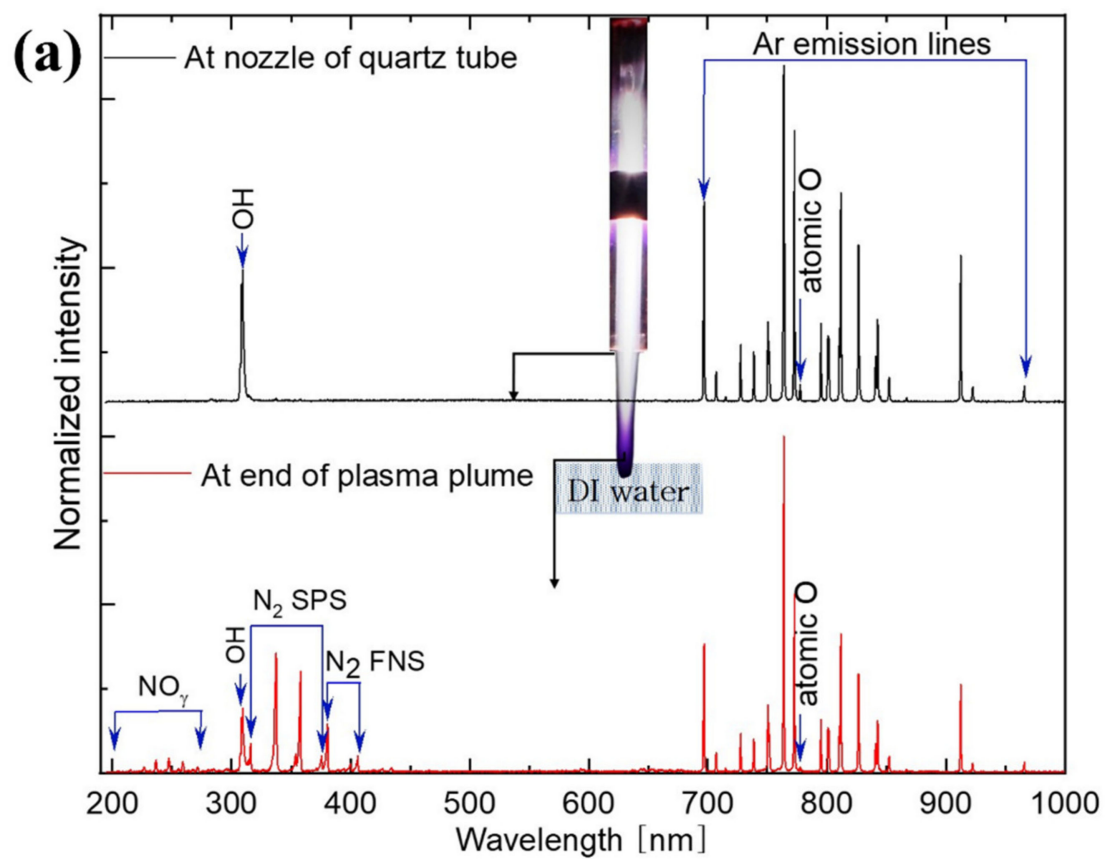

Horizontal distance $[\mathrm{cm}]$

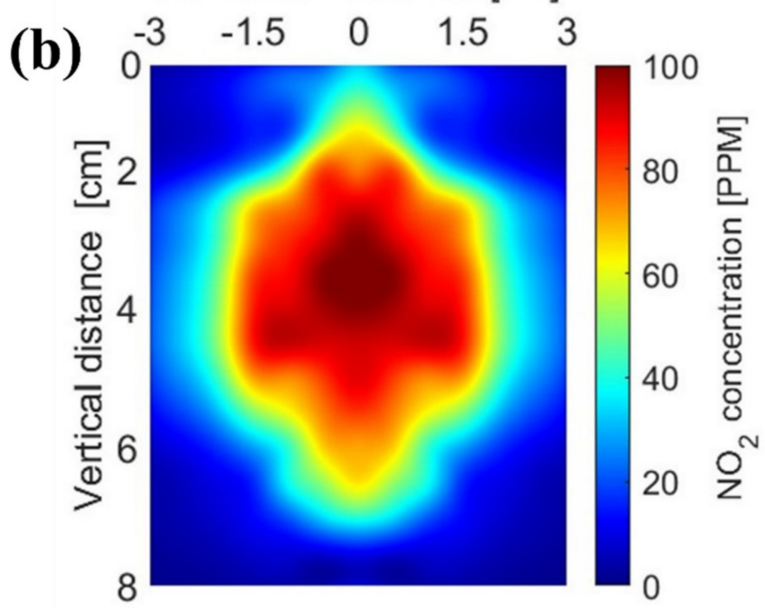

Figure 2. (a) Optical emission spectra of the plasma plume at the end of the quartz tube (black lines) and at the end of the plasma plume (red lines). (b) Longitudinal and transverse spatial distribution of $\mathrm{NO}_{2}$ for the plasma plume near the nozzle of the quartz tube.

When a plasma jet enters an aqueous solution, additional reactive species could be generated from the interaction between plasma radicals and water molecules [20]. Reactive oxygen and nitrogen intermediates $\left(\mathrm{OH}, \mathrm{O}_{2}^{-}, \mathrm{NO}, \mathrm{NO}_{2}\right.$, and $\left.\mathrm{NO}_{3}^{-}\right)$are converted into stable end products, hydrogen peroxide $\left(\mathrm{H}_{2} \mathrm{O}_{2}\right)$ and nitric acid $\left(\mathrm{HNO}_{3}\right)[30,31]$, that can play key roles in deactivating microbial cells. As shown in Figure 3, the PAW was acidified by the nitric acid formed in water by the plasma jet, but the PA-Mg-W had a higher $\mathrm{pH}$. In the PAW and PA-Mg-W, the possible nitrate generation and nitrate capture pathways were as follows [32-43]:

$$
\begin{gathered}
\mathrm{Ar}+e^{-} \rightarrow \mathrm{Ar}^{*}+e^{-} \\
\mathrm{O}_{2}+\mathrm{Ar}^{*} \rightarrow \mathrm{O}+\mathrm{O}+\mathrm{Ar} \\
\mathrm{N}_{2}+\mathrm{Ar}^{*} \rightarrow \mathrm{N}+\mathrm{N}+\mathrm{Ar} \\
\mathrm{N}_{2}+\mathrm{Ar}^{*} \rightarrow \mathrm{N}_{2}^{*}+\mathrm{Ar}
\end{gathered}
$$




$$
\begin{gathered}
\mathrm{H}_{2} \mathrm{O}+\mathrm{Ar}^{*} \rightarrow \mathrm{H}^{+}+\mathrm{OH}+\mathrm{Ar} \\
\mathrm{N}_{2}^{*}+\mathrm{O} \rightarrow \mathrm{NO}+\mathrm{N} \\
\mathrm{N}+\mathrm{OH} \rightarrow \mathrm{NO}+\mathrm{H} \\
\mathrm{N}+\mathrm{O} \rightarrow \mathrm{NO} \\
\mathrm{NO}+\mathrm{O} \rightarrow \mathrm{NO}_{2} \\
\mathrm{NO}+\mathrm{OH}+M^{*} \rightarrow \mathrm{HNO}_{2}+M \\
\mathrm{HNO}_{2}+\mathrm{O} \rightarrow \mathrm{OH}+\mathrm{NO}_{2} \\
\mathrm{O}_{2}+e^{-} \rightarrow \mathrm{O}_{2}^{-} \\
\mathrm{NO}^{-} \mathrm{O}_{2}^{-} \rightleftharpoons \mathrm{NO}_{3}^{-} \\
\mathrm{H}^{+}+\mathrm{O}_{2}^{-} \rightleftharpoons \mathrm{HO}_{2} \\
\mathrm{HO}_{2}+\mathrm{HO}_{2} \rightarrow \mathrm{H}_{2} \mathrm{O}_{2}+\mathrm{O}_{2} \\
\mathrm{NO}_{+} \mathrm{HO}_{2}+M^{*} \rightarrow \mathrm{NO}_{3}^{-}+\mathrm{H}^{+}+M \\
\mathrm{NO}_{2}+\mathrm{OH}^{+}+M^{*} \rightarrow \mathrm{NO}_{3}^{-}+\mathrm{H}^{+}+M \\
\mathrm{NO}_{3}^{-}+\mathrm{H}^{+} \rightarrow \mathrm{HNO}_{3} \\
\mathrm{Mg}_{(s)} \rightleftharpoons \mathrm{Mg}_{(a q)}^{2+}+e_{(a q)}^{-} \\
\mathrm{H}^{+}+e_{(a q)}^{-} \rightarrow \mathrm{H}^{2} \\
\mathrm{Mg}_{(s)}+2 \mathrm{H}^{+} \rightarrow \mathrm{Mg}_{(a q)}^{2+}+\mathrm{H}_{2(g)} \\
2 \mathrm{NO}_{3}^{-}+\mathrm{Mg}_{(a q)}^{2+} \rightleftharpoons \mathrm{Mg}_{\left(\mathrm{NO}_{3}\right)_{2}}
\end{gathered}
$$

where $\mathrm{Ar}^{*}$ denotes the metastable $4 s$ state of argon; $M^{*}$ is an arbitrary reaction partner such as $\mathrm{Ar}^{*}$ or $\mathrm{N}_{2}^{*}$; and $e^{-}$and $e_{(a q)}^{-}$are dry (nonhydrated) and wet (hydrated) electrons, respectively. In the plasma jet, $\mathrm{N}$ and $\mathrm{O}$ are generated by excited species from the dissociation of $\mathrm{O}_{2}$ and $\mathrm{N}_{2}$ (Equations (2) and (3)). $\mathrm{NO}$ and $\mathrm{NO}_{2}$ can be produced via various reaction pathways (Equations (6)-(11)). The main reaction leading to the generation of $\mathrm{NO}$ is Equation (7) [32]. Meanwhile, most $\mathrm{NO}_{2}$ is generated through the oxidation of $\mathrm{NO}$ (Equation (9)) [32]. $\mathrm{NO}$ and $\mathrm{NO}_{2}$ can be converted into $\mathrm{NO}_{3}^{-}$ions (Equations (16) and (17)). In the PAW, water acidification was caused by plasma-generated hydrogen ions $\left(\mathrm{pH}=-\log _{10}\left[\mathrm{H}^{+}\right]\right.$) (Equation (5)). When $\mathrm{ZVM}$ was added to the water, magnesium dications $\left(\mathrm{Mg}^{2+}\right)$ were formed in the aqueous solution by plasma-generated hydrogen ions (Equation (21)), as shown in Figure 4. To detect the $\mathrm{Mg}^{2+}$ ion concentration in the PA-Mg-W, water containing a square disk-shaped $\mathrm{Mg}$ block (disk area = $1.0 \mathrm{~cm} \times 1.0 \mathrm{~cm}$ and disk height $=0.5 \mathrm{~cm}$ ) was treated by the plasma jet for $10 \mathrm{~min}$, and then the $\mathrm{Mg}$ block was removed. The resulting $\mathrm{Mg}^{2+}$ ion concentration was measured to be $80 \mathrm{mM}$ by inductively coupled plasma (ICP)-OES. When the Mg block was immersed in water for $10 \mathrm{~min}$ without the plasma jet, the $\mathrm{Mg}^{2+}$ ion concentration in water was measured to be $0.26 \mathrm{mM}$. The formation of magnesium ions is facilitated in the acidic conditions caused by the plasma treatment. In the PA-Mg-W, $\mathrm{Mg}^{2+}$ ions can combine with the plasma-generated nitrate ions (Equation (22)). That is, free nitrate ions are converted into a stable nitrate salt, resulting in a reduction in free nitrate ions. The amount of formed nitrate salt depends on the number of $\mathrm{Mg}^{2+}$ ions. More $\mathrm{Mg}^{2+}$ ions can combine with more $\mathrm{NO}_{3}^{-}$ions. The formation of nitrate salt will reduce the level of free nitrate ions, leading to a reduction in the antifungal effect by PAW. When nitrate salt is produced, $\mathrm{HNO}_{3}$ formation is suppressed (Equations (18) and (22)), and the PAW tends to be neutralized (Equations (20) and (22)) [13,44]. 


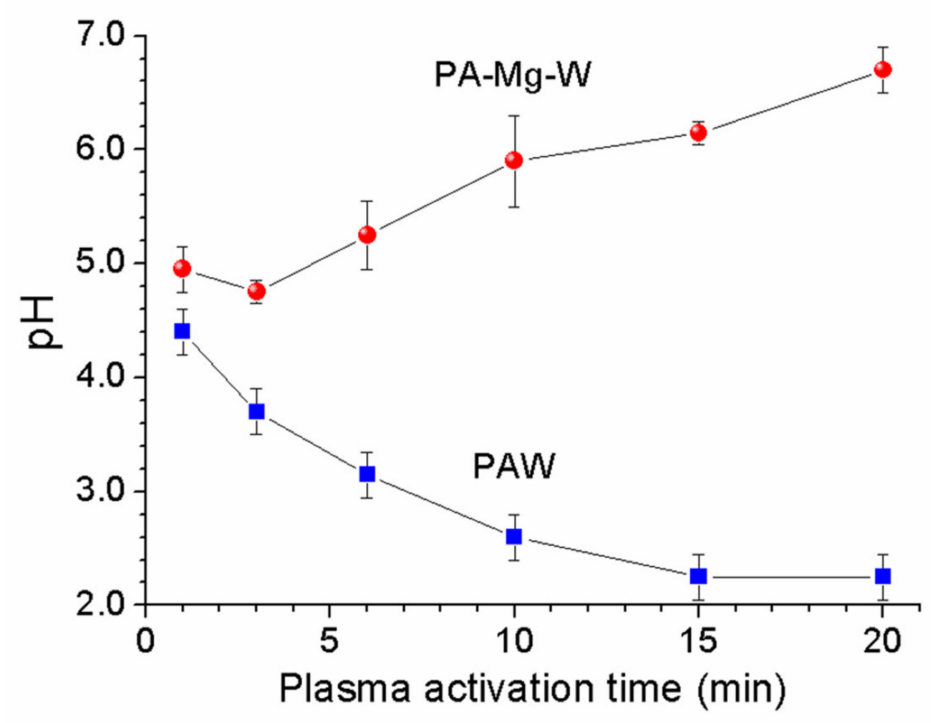

Figure 3. The $\mathrm{pH}$ of the PAW and PA-Mg-W as a function of the plasma activation time.

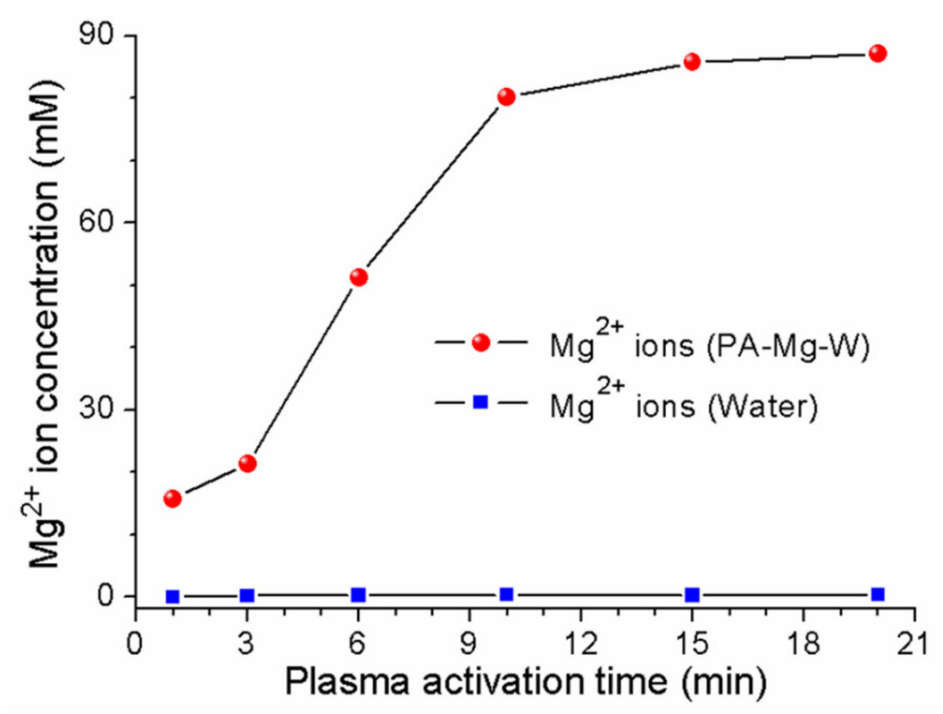

Figure 4. $\mathrm{Mg}^{2+}$ ion concentrations in PA-Mg-W as a function of the plasma activation time. Redcolored circles and blue-colored squares represent $\mathrm{Mg}^{2+}$ ion concentrations when the $\mathrm{Mg}$ block was immersed in water for $10 \mathrm{~min}$ with and without the plasma jet, respectively, and then the $\mathrm{Mg}$ block was excluded from water.

\subsection{Optical Absorption Properties of Plasma-Activated Mg Water}

The optical absorption spectra of the PAW and PA-Mg-W are shown in Figure $5 \mathrm{a}, \mathrm{b}$, respectively. The absorption spectra of the reference free nitrate and nitrate salt $\left(\mathrm{Mg}\left(\mathrm{NO}_{3}\right)_{2} \cdot 6 \mathrm{H}_{2} \mathrm{O}\right)$ solutions are shown in Figure $5 \mathrm{c}$. In this research, the commercial Oakton $1000 \mathrm{ppm}$ nitrate standard was used as the reference free nitrate. The absorption spectra of the PAW and PA-Mg-W are similar to those of the reference nitrate and nitrate salt solutions. The DW was optically transparent in the UV and visible regions, but the absorption spectra of the PAW and PA-Mg-W exhibited a resonance absorption band at $\lambda \simeq 300 \mathrm{~nm}$ that is attributable to the nitrate ions produced in the PAW and PA-Mg-W by the plasma jet [45]. Longer plasma activation times produced higher concentrations of nitrate ions in the PAW and PA-Mg-W. To further investigate the plasma-induced nitrogen species, we diluted the PAW and PA-Mg-W and measured the optical absorption spectra over a wavelength range of $190-250 \mathrm{~nm}$ using a quartz cell with an optical path 
length of $2 \mathrm{~mm}$. As shown in Figure 5d, the absorption spectra of the PAW and PA-Mg-W exhibited an absorption peak at $201 \mathrm{~nm}$. As the reference nitrite and nitrate solutions have absorption peaks at 209 and $201 \mathrm{~nm}$, respectively [12,46], the observed 201-nm absorption band indicates that nitrate ions greatly outnumber nitrite ions. Next, the nitrate absorption peak intensity at $300 \mathrm{~nm}$ was higher in the PA-Mg-W than in the PAW, as shown in Figure $5 \mathrm{a}, \mathrm{b}$. As calculated from the molar absorption coefficient of the reference nitrate solution, the nitrate concentration in the PAW treated by the plasma jet for $10 \mathrm{~min}$ was estimated to be $86 \mathrm{mM}$. When $\mathrm{Mg}$ water was treated by the plasma jet for $10 \mathrm{~min}$, the free and bound nitrate concentrations in the PA-Mg-W were estimated to be 42 and $160 \mathrm{mM}$, respectively. The bound nitrate concentration in the PA-Mg-W was estimated from the $\mathrm{Mg}^{2+}$ ion concentration measured by ICP-OES (Figure 4), and the free nitrate concentration in the PA-Mg-W was obtained by subtracting the bound nitrate concentration from the total nitrate concentration. For PA-Mg-W and PAW with plasma treatment times between 10 and $20 \mathrm{~min}$, the free nitrate concentration was lower in the PA-Mg-W than in the PAW (Figure 5e). These results indicate that plasma-generated $\mathrm{Mg}^{2+}$ ions can reduce the level of free nitrate ions in the PAW by forming nitrate salt. When DW and $\mathrm{Mg}-\mathrm{W}$ were treated by the plasma jet for $10 \mathrm{~min}$, the $\mathrm{H}_{2} \mathrm{O}_{2}$ concentration in the PAW and PA-Mg-W were estimated to be $98 \mu \mathrm{M}$ and $88 \mu \mathrm{M}$, respectively, confirming that nitrate ions in the PAW and PA-Mg-W were the dominant reactive species that could affect the biological components of cells $[47,48]$.
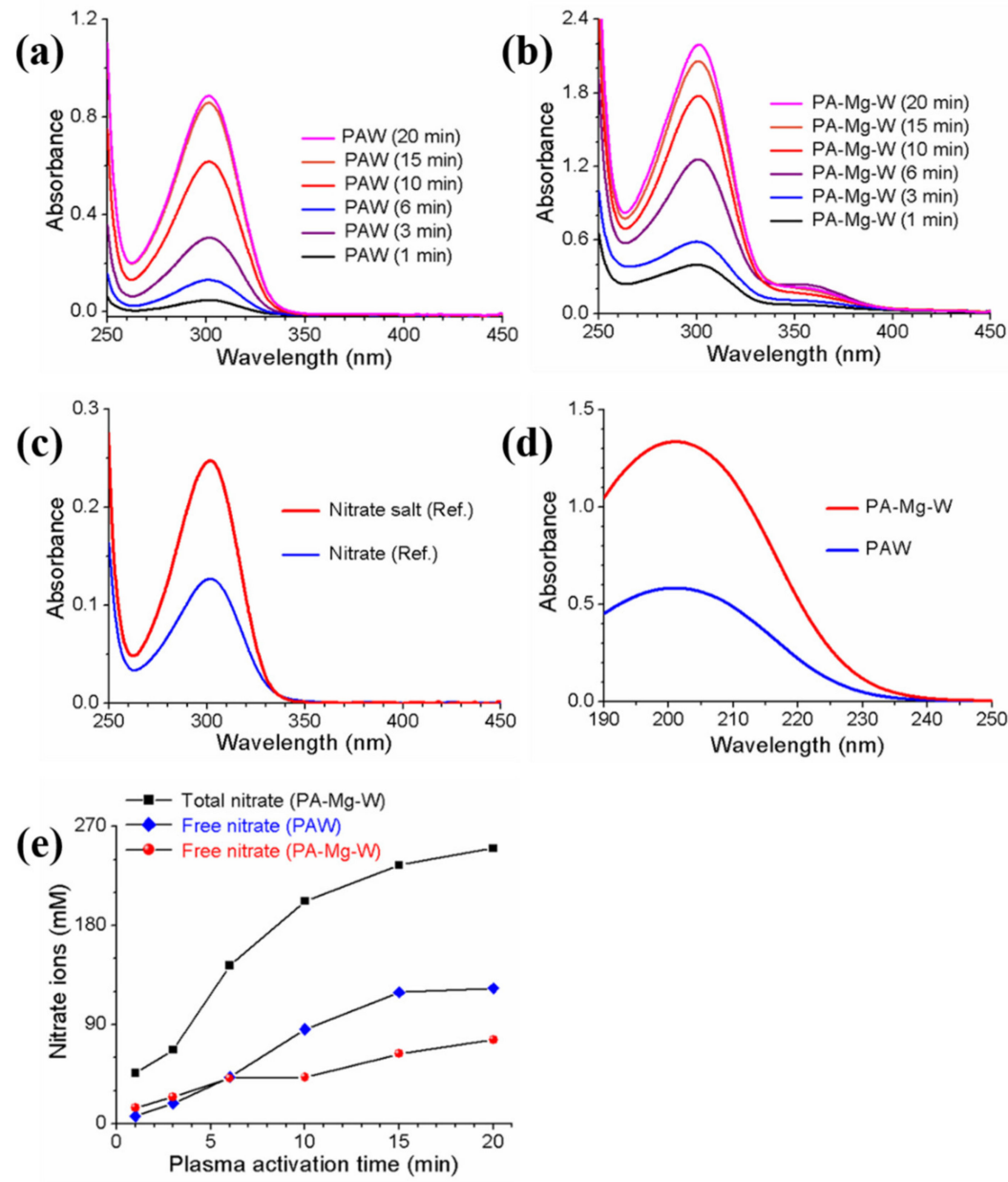

Figure 5. UV-visible absorption spectra of the (a) PAW and (b) PA-Mg-W over a wavelength range of $250-450 \mathrm{~nm}$. (c) Absorption spectra of the reference free nitrate and nitrate salt $\left(\mathrm{Mg}\left(\mathrm{NO}_{3}\right)_{2} \cdot 6 \mathrm{H}_{2} \mathrm{O}\right)$ solutions. (d) Absorption spectra of the PAW and PA-Mg-W over a wavelength range of 190-250 nm. (e) Nitrate ion concentrations in the PAW and PA-Mg-W. 


\subsection{Raman Spectroscopic Study of Plasma-Activated Mg Water}

Figure 6a shows the Raman spectra of the PAW and PA-Mg-W. The Raman spectra of the reference free nitrate and nitrate salt $\left(\mathrm{Mg}\left(\mathrm{NO}_{3}\right)_{2} \cdot 6 \mathrm{H}_{2} \mathrm{O}\right)$ solutions are shown in Figure 6b. The Raman spectra of the PAW and PA-Mg-W exhibited several peaks attributable to specific vibration modes of water molecules and plasma-generated nitrate ions. As is well known, Raman bands in the frequency range of 3200 to $3600 \mathrm{~cm}^{-1}$ can be assigned to overlap the stretching vibration modes of water molecules at 3223 and $3422 \mathrm{~cm}^{-1}$, and the Raman band at $1630 \mathrm{~cm}^{-1}$ is due to the $\mathrm{OH}$ bending mode of water molecules $[49,50]$. The reference nitrate salt, PAW, and PA-Mg-W all exhibited an intense Raman band at $1049 \mathrm{~cm}^{-1}$, which is attributable to the symmetrical stretching vibration mode of nitrate ions [51-53]. Longer plasma activation times produced stronger Raman intensity because of the accumulation of plasma-induced nitrate ions. The $1049 \mathrm{~cm}^{-1}$ Raman band intensity is higher in the PA-Mg-W than in the PAW, as shown in Figure 6c, because the Raman scattering intensity of the bound nitrate ions in nitrate salt is stronger than that of free nitrate ions, as shown in Figure 6b. The Raman enhancement indicates that $\mathrm{Mg}^{2+}$ ions can convert free nitrate to bound nitrate by forming nitrate salt. To summarize, the Raman spectra of the PA-Mg-W and reference nitrate salt all exhibited a strong Raman peak near $1049 \mathrm{~cm}^{-1}$, indicating that $\mathrm{Mg}^{2+}$ and $\mathrm{NO}_{3}^{-}$ions formed solvent-shared ion-pairs $\left(\mathrm{Mg}\left(\mathrm{NO}_{3}\right)_{2} \cdot 6 \mathrm{H}_{2} \mathrm{O}\right)$ in the aqueous solution [53]. These results indicate that the intense Raman band at $1049 \mathrm{~cm}^{-1}$ is attributable to the capture of nitrate by $\mathrm{Mg}^{2+}$ ions. Therefore, the $1049 \mathrm{~cm}^{-1}$ Raman peak could be used as a fingerprint to confirm the capture of nitrate in PAW by magnesium ions.
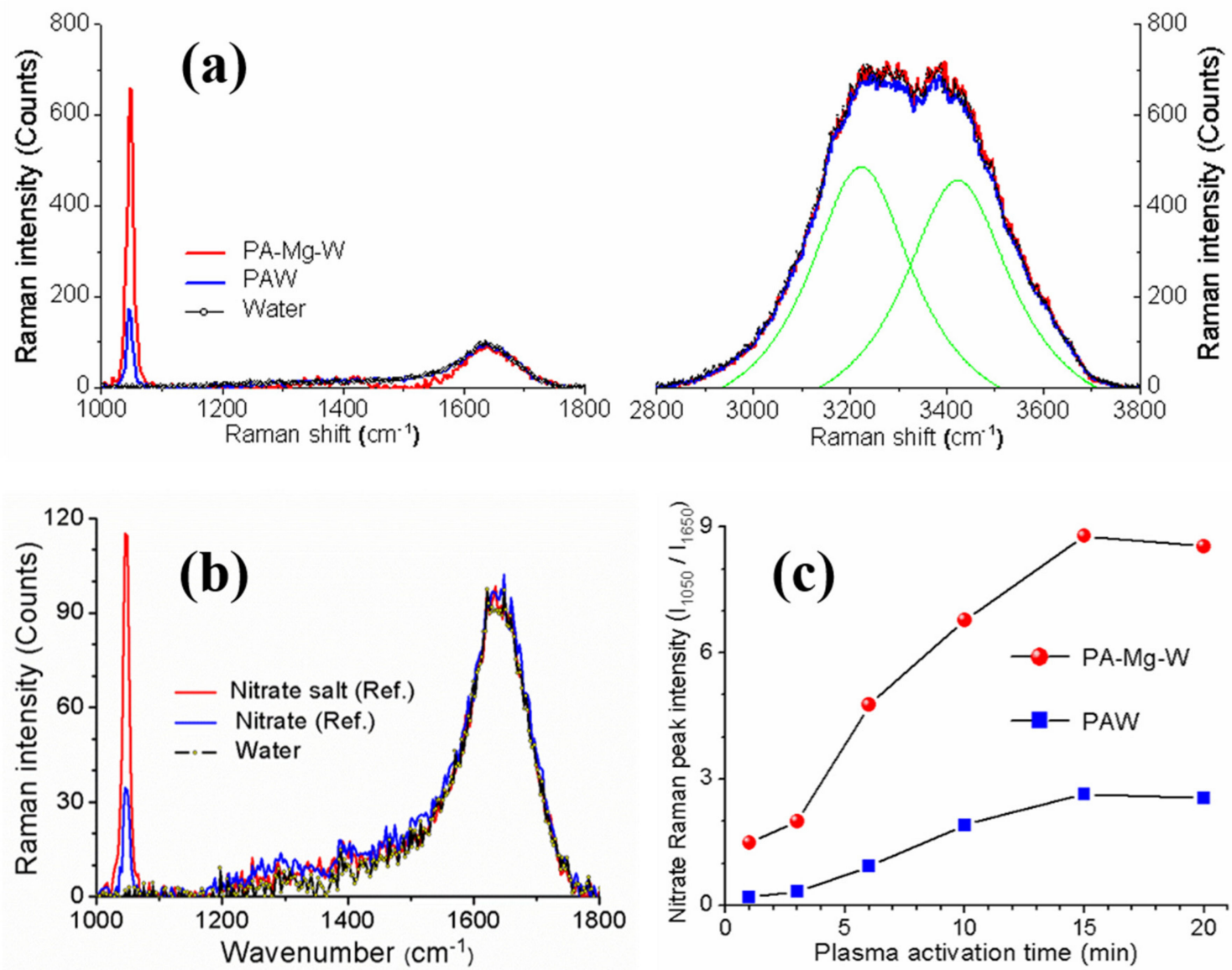

Figure 6. (a) Raman spectra of the PAW and PA-Mg-W. (b) Raman spectra of the reference free nitrate and nitrate salt solutions. (c) Nitrate Raman peak intensity as a function of plasma activation time. In (a), the Raman spectra were measured for PAW and PA-Mg-W treated by the plasma jet for $10 \mathrm{~min}$. 


\subsection{Antifungal Effects of Plasma-Activated Water on C. pseudolongus Cells}

The cell walls of Ascomycota and Basidiomycota fungi contain chitin together with $\beta-1,3, \beta-1,6-$ linked glucans in fibrous form. However, their structural compositions differ in the types of glycoprotein. That is, Ascomycota fungi are characterized by gel-like $\alpha-1,3$ glucans and galactomannoproteins, whereas Basidiomycota fungi are characterized by $\alpha-1,3$ glucans along with xylomannoproteins [54]. In a previous work, we demonstrated that PAW influences the spore viability and cell wall integrity of the Ascomycota fungus, Aspergillus brasiliensis, which has melanized fungal spores [12]. We wondered whether PAW would be applicable to Basidiomycota fungi. The cell wall of the basidiomycetous yeast Cryptococcus is enveloped by a gelatinous capsule composed of glucuronoxylomannan and galactoxylomannan that is anchored to the main wall via $\alpha-1,3$ glucan. Therefore, we decided to test the antifungal effects of PAW on the Basidiomycota fungus. In addition, we investigated the possibility that the antifungal effects of PAW on the fungus could be manipulated through the capture of nitrate by magnesium ions. When testing antimicrobials, it is common to test at different concentrations to ensure that the effect appears in a concentration-dependent manner. Thus, we diluted the PAW and PA-Mg-W for the antifungal effect on the fungal cells. Both the PAW and PA-Mg-W treatments against $C$. pseudolongus cells revealed a remarkable effect on the viability of the fungal cells, as shown in Figure 7a. PAW-5 and PA-Mg-W-5 solutions were prepared by treating DW and $\mathrm{Mg}-\mathrm{W}$ with a plasma jet for $10 \mathrm{~min}$, respectively. PAW-1 (0.14 mM nitrate), PAW-2 (0.69 mM nitrate), PAW-3 (3.4 mM nitrate), and PAW-4 (17 mM nitrate) were prepared by diluting PAW-5 (86 mM nitrate) with DW. PA-Mg-W-1 (0.26 mM nitrate salt), PA-Mg-W-2 (1.3 mM nitrate salt), PA-Mg-W-3 (6.3 mM nitrate salt), and PA-Mg-W-4 (32 mM nitrate salt) were prepared by diluting PA-Mg-W-5 (160 mM nitrate salt) with DW. After being treated for $24 \mathrm{~h}$ in the PAW-5 solution, the fungal cell viability dropped to less than $1 \%$, indicating that the PAW treatment effectively sterilized most of the tested C. pseudolongus cells. Longer plasma activation times lowered the fungal cell viabilities. The PAW-3 (3.4 mM nitrate) treatment exhibited cell viability of 53\%. The PAW treatment reduced cell viability in a nitrate concentration-dependent manner (Figure 7a). The yeast type fungal cells are more sensitive in a low $\mathrm{pH}$ environment which could be established with a higher nitrate concentration (Figure $7 \mathrm{~b}$ ). The dilution of PAW with DW lowers free nitrate ion concentrations, makes the water less acidic, and leads the yeast cells to be less sensitive. Therefore, PAW can also destroy the cells of Basidiomycota fungi encapsulated by a relatively thick cell wall. These results demonstrated that the PAW produced by the atmospheric-pressure Ar plasma jet is detrimental not only to Ascomycota fungal spores which were produced by conidiophores [12] but also to Basidiomycota yeast cells which were produced by budding. From the viewpoint of applications such as sanitary means, it is meaningful that the two taxonomically different major groups of fungi are susceptible enough to the PAW produced by the plasma jet. Because nitrate ions were stable and long-lived reactive species and were confirmed to be present in the PAW from the optical absorption and Raman scattering spectra, we assume that the plasma-generated nitrate ions in the PAW were the key agents for the C. pseudolongus cell inactivation.

To provide evidence that nitrate ions can work against this fungal cell viability, we investigated the effect of a reference free nitrate treatment on the fungal cells. For this investigation, C. pseudolongus cells were treated with $\mathrm{HNO}_{3}$ solutions with nitrate concentrations similar to those in the PAW. As shown in Figure $7 \mathrm{~b}, \mathrm{HNO}_{3}$ treatments inactivated the $C$. pseudolongus cells. These results demonstrate that nitrate ions reduce the survival of fungal cells. Next, we found that the PA-Mg-W treatment also decreased the viability of fungal cells, as shown in Figure 7a. This result shows that the PA-Mg-W treatment also gives rise to an antifungal effect. When we compared the treatment effects of PAW and PA-Mg-W, C. pseudolongus cells had higher viability with the PA-Mg-W treatment. Therefore, the antifungal effect of PAW could be changed through nitrate capture. In fact, the viability of the PA-Mg-W-1 (0.26 mM nitrate salt)-treated cells were slightly higher than that of the control cells. Considering that nitrate can serve as a major source of nitrogen 
for most algae, bacteria, fungi, and higher plants and is the nutrient that most frequently limits their growth [55], we cannot rule out the possibility that the PA-Mg-W treatment at a particular concentration might enable cell growth of the fungus. However, further study is needed to verify that assumption. Nitrate salt $\left(\mathrm{Mg}\left(\mathrm{NO}_{3}\right)_{2} \cdot 6 \mathrm{H}_{2} \mathrm{O}\right)$ solution treatments also showed higher cell viability than $\mathrm{HNO}_{3}$ solution treatments. The difference in viability between the PAW-treated cells and PA-Mg-W-treated cells is attributed to the decrease in free nitrate ions resulting from the formation of nitrate salts. Therefore, nitrate capture could attenuate the antifungal effect of PAW on C. pseudolongus cells.
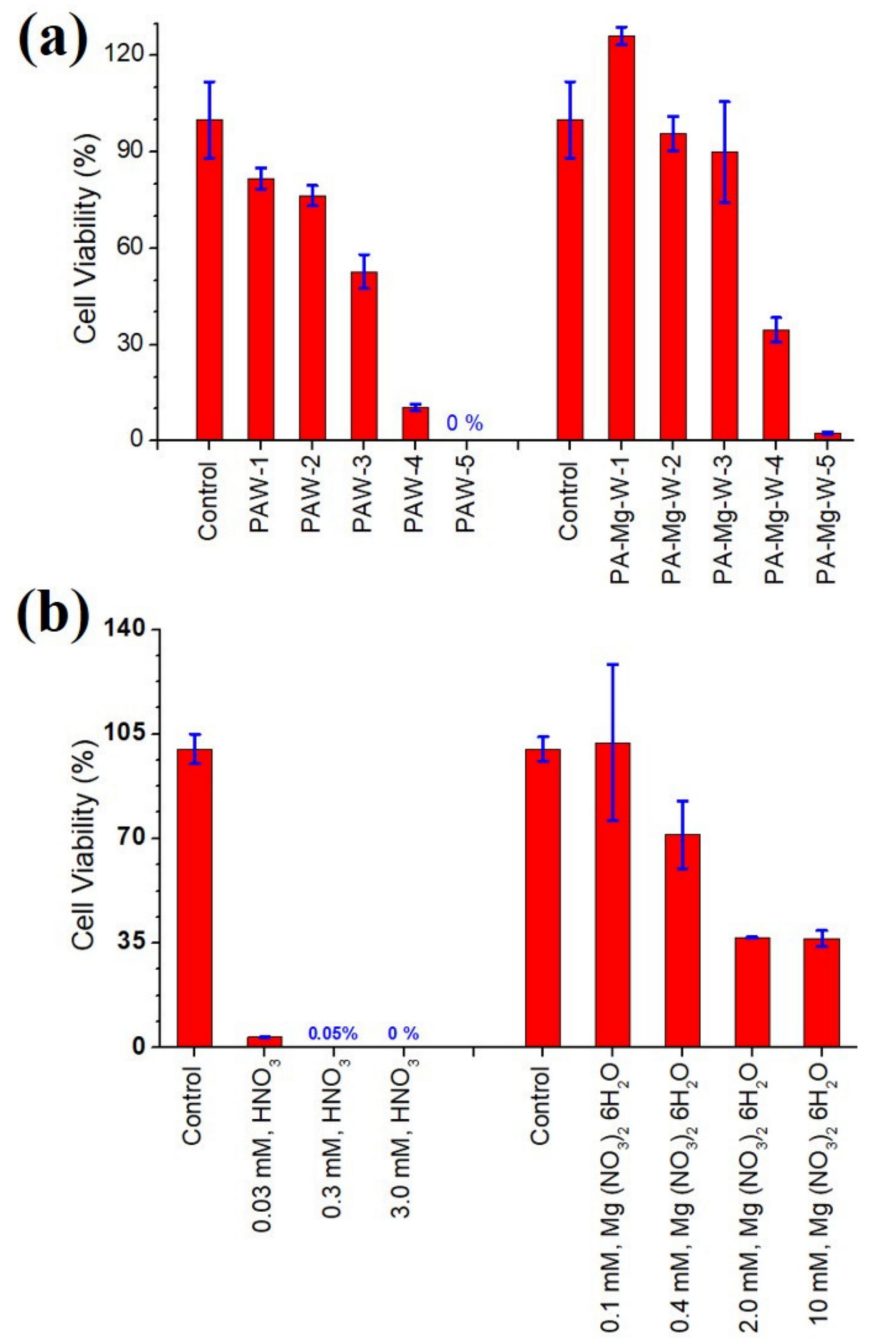

Figure 7. (a) Viability of C. pseudolongus cells treated with PAW and PA-Mg-W. The free nitrate ion concentrations were $0.14,0.69,3.4,17$, and $86 \mathrm{mM}$ for PAW-1, PAW-2, PAW-3, PAW-4, and PAW-5, respectively. The nitrate salt concentrations were $0.26,1.3,6.3,32$, and $160 \mathrm{mM}$ for PA-Mg-W-1, PA-Mg-W-2, PA-Mg-W-3, PA-Mg-W-4, and PA-Mg-W-5, respectively. (b) Viability of C. pseudolongus cells treated with nitric acid $\left(\mathrm{HNO}_{3}\right)$ and nitrate salt $\left(\mathrm{Mg}\left(\mathrm{NO}_{3}\right)_{2} \cdot 6 \mathrm{H}_{2} \mathrm{O}\right)$ solutions. The fungal cells were in contact with PAW and reference nitric acid (nitrate salt) solutions for $24 \mathrm{~h}$.

\section{Materials and Experimental Methods}

3.1. Characterizations of the Atmospheric-Pressure Ar Plasma Jet and Plasma-Activated Mg Water

Figure 8 illustrates the experimental layout of our atmospheric-pressure Ar plasma jet and the photograph of a plasma plume. The plasma jet was created from a stainless steel needle electrode (length $35 \mathrm{~mm}$, outer diameter $0.9 \mathrm{~mm}$, and inner diameter $0.6 \mathrm{~mm}$ ) inserted inside a quartz tube (length $55 \mathrm{~mm}$, outer diameter $4 \mathrm{~mm}$, and inner diameter $2 \mathrm{~mm}$ ). The peripheral region between the top of the quartz tube and the needle electrode 
was sealed with a Torr seal. Argon gas entered the quartz tube through the opening of the needle. The flow rate of argon gas was continuously maintained at $1000 \mathrm{sccm}$. A specially designed DC-to-AC inverter with a repetition frequency of $33 \mathrm{kHz}$ was used as the driving source to produce the plasma. For grounding, copper tape (width $3 \mathrm{~mm}$ ) was wrapped around the quartz tube $5 \mathrm{~mm}$ below the lower tip of the power electrode. When an alternating sinusoidal voltage of $\cong 6 \mathrm{kV}$ (peak-to-peak) was applied, plasma was produced between the two electrodes and then propagated along the quartz tube to reach air under ambient atmospheric pressure conditions. The plasma was then produced within the quartz tube below the lower tip of the needle. To obtain PAW in this experiment, the plasma was directly injected into the surface of $4 \mathrm{~mL}$ DI water with and without an immersed $\mathrm{Mg}$ block placed $25 \mathrm{~mm}$ away from the nozzle of the quartz tube.

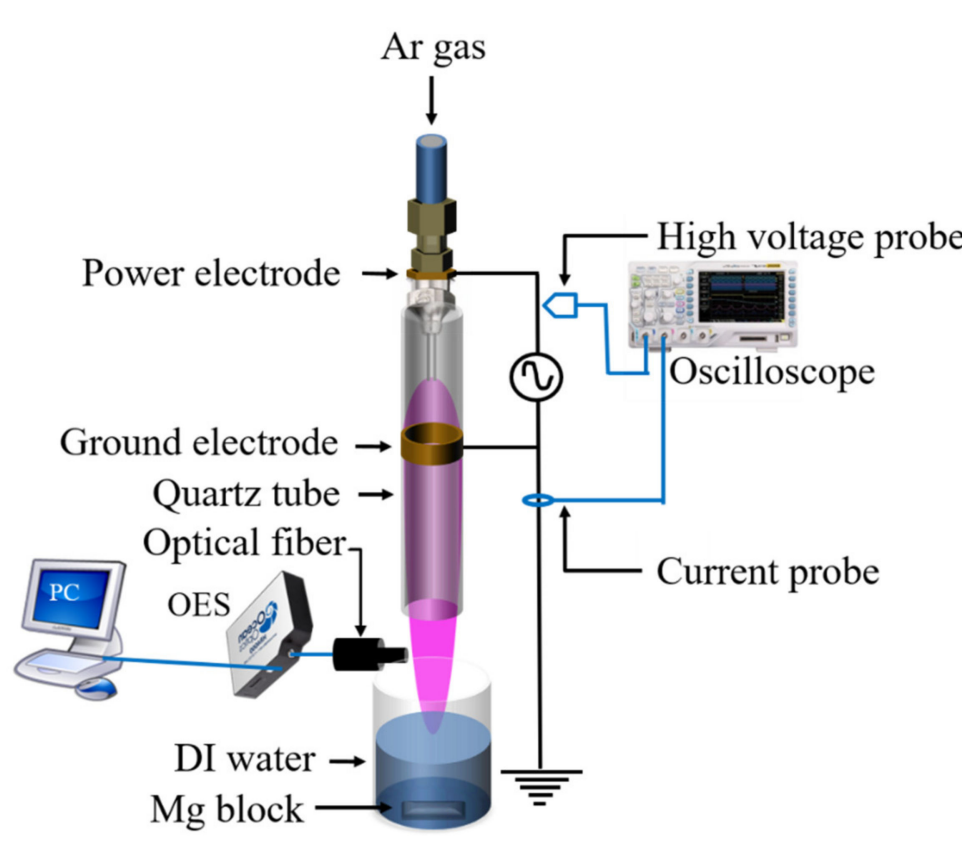

(a)

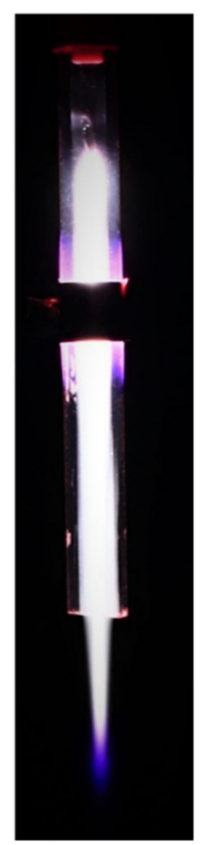

(b)

Figure 8. (a) Experimental setup of our atmospheric-pressure argon plasma jet system and (b) photograph of plasma plume. In (a), the plasma plume is pink-colored.

The discharge voltage and discharge current were measured with a high-voltage probe (P6015A, Tektronix, Inc., Beaverton, OR, USA) and a current probe (CP030, LeCroy Corporation, Chestnut Ridge, NY, USA), respectively. The optical emission spectra of the plasma jet were measured using a fiber optic spectrometer (HR4000, Ocean Optics Inc., Dunedin, FL, USA). The spectrometer was wavelength-calibrated using a Hg-Ar lamp (6048, Newport Corporation, Irvine, CA, USA). To find the nitrate ion content in the PAW with and without Mg, UV-visible absorption spectra were measured using an optical spectrometer (J-815, Jasco Inc., Easton, MD, USA). Nitrate ion concentration in the PAW was obtained from the molar absorption coefficient of the reference free nitrate solution, and nitrate ion concentrations in the PA-Mg-W were obtained from the molar absorption coefficient of the reference nitrate salt $\left(\mathrm{Mg}\left(\mathrm{NO}_{3}\right)_{2} \cdot 6 \mathrm{H}_{2} \mathrm{O}\right)$ solution. The concentrations of $\mathrm{H}_{2} \mathrm{O}_{2}$ in the PAW were measured using the QuantiChrom ${ }^{\mathrm{TM}}$ Peroxide Assay Kit (DIOX-250) (BioAssay Systems, Hayward, CA, USA). To examine $\mathrm{Mg}^{2+}$ ions in the PA-Mg-W, total $\mathrm{Mg}^{2+}$ ion concentrations were measured via ICP-OES (Optima 2100 DV, Perkin-Elmer, Waltham, MA, USA) analyses after digestion in nitric acid following the 3500-Mg A standard method. To study the capture of nitrate in the PAW by magnesium ions, Raman spectra of the PAW and PA-Mg-W were measured at room temperature using a confocal Raman microscope (Alpha 300R, WiTec, Ulm, Germany) with a $632.8 \mathrm{~nm}$ He-Ne laser. To obtain the Raman 
spectra for the nitrate ions in the PAW, the incident laser beam was focused onto the PAW using a microscope objective $(20 \times)$. The scattered light was collected by the same objective lens, dispersed by a grating, and then detected by a charge-coupled device array detector.

\subsection{Fungal Growth and Antifungal Test of Plasma-Activated Mg Water}

To test the antifungal effects of the PAW and PA-Mg-W, the mushroom pathogen Cryptococcus pseudolongus DUCC 4014 was used [15]. The antifungal test was performed against the yeast-like cells produced by this fungus. The fungus was maintained on potato dextrose agar (PDA; Thermo Fisher Scientific, Seoul, Korea) at $25^{\circ} \mathrm{C}$ for 14 days. To prepare the cells, the fungal strain was grown in potato dextrose broth (Thermo Fisher Scientific, Seoul, Korea) on a shaker for 3 days at $25^{\circ} \mathrm{C}$. The cultured fungal broth was centrifuged at 8000 RPM for $5 \mathrm{~min}$, the supernatant was removed, and the precipitated fungal cells were obtained. Sterile water was added to suspend the obtained fungal cells. The number of fungal cells was counted using a hemocytometer (Sigma-Aldrich, Bright-Line ${ }^{\mathrm{TM}}$, St. Louis, MO, USA) and an optical microscope (Axioskop40, Carl Zeiss, Jena, Germany). Before PAW (PA-Mg-W) treatments, the concentration of fungal cells in water was adjusted to $5 \times 10^{8} / \mathrm{mL}$. One volume of the prepared fungal cells was added to nine volumes of PAW (PA-Mg-W) so that the final concentration of fungal cells in PAW (PA-Mg-W) was $5 \times 10^{7} / \mathrm{mL}$. After vortexing lightly, the fungal cells were treated with PAW (PA-Mg-W) for $24 \mathrm{~h}$ at room temperature. After centrifugation at $8000 \mathrm{RPM}$ for $5 \mathrm{~min}$, the supernatant was discarded, and the cells were dissolved with sterile DW. The dissolved fungal cells were diluted 10-fold with sterile DW, spread on PDA medium in three replicates, and incubated at $25{ }^{\circ} \mathrm{C}$ for $48 \mathrm{~h}$, which was long enough to observe the surviving cells. The fungal colonies grown out on the plates were counted with a colony counter, and the number of colony-forming units was calculated to measure cell viability. To examine the effects of the reference free nitrate and nitrate salt solutions on the fungal cells, those solutions were prepared in different concentrations $\left(0.03 \mathrm{mM}, 0.3 \mathrm{mM}\right.$, and $3.0 \mathrm{mM}$ for the $\mathrm{HNO}_{3}$ solutions and $0.1 \mathrm{mM}, 0.4 \mathrm{mM}, 2.0 \mathrm{mM}$, and $10 \mathrm{mM}$ for the $\mathrm{Mg}\left(\mathrm{NO}_{3}\right)_{2} \cdot 6 \mathrm{H}_{2} \mathrm{O}$ solutions). The fungal cells were treated with each concentration of $\mathrm{HNO}_{3}$ and $\mathrm{Mg}\left(\mathrm{NO}_{3}\right)_{2} \cdot 6 \mathrm{H}_{2} \mathrm{O}$ solutions for $24 \mathrm{~h}$, as with the PAW and PA-Mg-W. Then the treated cells were centrifuged at $8000 \mathrm{rpm}$ for $5 \mathrm{~min}$, the supernatant was discarded, and the precipitated cells were dissolved with sterile DW. The dissolved fungal cells were analyzed for their viability as described for the PAW and PA-Mg-W treatments.

\section{Conclusions}

In conclusion, we demonstrated that the antifungal effects of PAW could be manipulated through the capture of nitrate by $\mathrm{Mg}^{2+}$ ions. Optical emission spectra of the plasma jet exhibited that ROS are dominant in the plasma plume at the end of the quartz tube, whereas RNS are dominant at the end of the plume, as shown by OES and the $\mathrm{NO}_{2}$ distribution of the plasma jet. The plasma treatment of DW produced acidified water. When $\mathrm{Mg}$ water was treated with the plasma jet, the acidity of the PA-Mg-W was weakened due to the reduction in the plasma-generated hydrogen ion by electrons released from the ZVM. Optical absorption and Raman spectra confirmed that nitrate ions were the dominant reactive species in the PAW and PA-Mg-W. Due to the formation of nitrate salts by $\mathrm{Mg}^{2+}$ ions, the free nitrate ion content was lower in the PA-Mg-W than in the PAW. The reduction in free nitrate ions in the PA-Mg-W is attributed to the formation of nitrate salts. Both the PAW and PA-Mg-W treatments against C. pseudolongus cells had a remarkable effect on the viability of the fungal cells. For PAW and PA-Mg-W treatments with the same plasma activation time, the viability of the fungal cells was higher in the PA-Mg-W than in the PAW. In parallel with the effort of development of new antifungal agents, there is increasing interest in the development of plasma devices to protect against the newly appeared fungal pathogens. From this work, we successfully extended the application of PAW from Ascomycota fungi to Basidiomycota fungi. This extension is also significant because PAW has effects on both yeast form and mycelial form cells which have different 
cell wall compositions. Consequently, we expect that PAW should be applied to antifungal therapies in various area in the very near future.

Author Contributions: Conceptualization, G.J.L., S.H.K., and E.H.C.; methodology, G.J.L., P.L., S.H.K., and E.H.C.; software, P.L., and S.J.A.; validation, G.J.L., S.H.K., and E.H.C.; formal analysis, G.J.L., S.H.K., and E.H.C.; investigation, G.J.L., P.L., and S.H.K.; resources, G.J.L., S.H.K., and E.H.C.; data curation, P.L., S.J.A., M.A.Y., C.E.C., and M.J.; writing—original draft preparation, G.J.L., P.L., and S.H.K.; writing-review and editing, G.J.L., S.H.K., and E.H.C.; visualization, G.J.L., P.L., and S.H.K.; supervision, G.J.L., S.H.K., and E.H.C.; funding acquisition, G.J.L., S.H.K., M.J., and E.H.C.; All authors have read and agreed to the published version of the manuscript.

Funding: This research was supported by the Basic Science Research Program through the National Research Foundation of Korea funded by the Ministry of Education, Republic of Korea (Grant number: NRF-2018R1D1A1B07040386, 2021R1A6A1A03038785), and in part by Kwangwoon University in 2021. This research was supported by the Korean Institute of Planning and Evaluation for Technology (IPET) in Food, Agriculture, and Forestry through the Golden Seed Project, funded by the Ministry of Agriculture, Food, and Rural Affairs in Korea [213007-05-5-SBH30], and the Department of Microbiology was supported through the Research Focused Department Promotion as a part of the University Innovation Program for Dankook University in 2021.

Institutional Review Board Statement: Not applicable.

Informed Consent Statement: Not applicable.

Data Availability Statement: Not applicable.

Conflicts of Interest: The authors declare no conflict of interest.

\section{References}

1. Zhou, R.; Zhou, R.; Wang, P.; Xian, Y.; Mai-Prochnow, A.; Lu, X.; Cullen, P.J.; Ostrikov, K.K.; Bazaka, K. Plasma-activated water: Generation, origin of reactive species and biological applications. J. Phys. D Appl. Phys. 2020, 53, 303001. [CrossRef]

2. Thirumdas, R.; Kothakota, A.; Annapure, U.; Siliveru, K.; Blundell, R.; Gatt, R.; Valdramidis, V.P. Plasma-activated water (PAW): Chemistry, physico-chemical properties, applications in food and agriculture. Trends Food Sci. Technol. 2018, 77, 21-31. [CrossRef]

3. Dobrynin, D.; Fridman, G.; Friedman, G.; Fridman, A. Physical and biological mechanisms of direct plasma interaction with living tissue. New J. Phys. 2009, 11, 115020. [CrossRef]

4. Lackmann, J.W.; Schneider, S.; Edengeiser, E.; Jarzina, F.; Brinckmann, S.; Steinborn, E.; Havenith, M.; Benedikt, J.; Bandow, J.E. Photons and particles emitted from cold atmospheric-pressure plasma inactivate bacteria and biomolecules independently and synergistically. J. R. Soc. Interface 2013, 10, 20130591. [CrossRef]

5. Laroussi, M. Low temperature plasma-based sterilization: Overview and state-of-the-art. Plasma Process. Polym. 2005,2 , 391-400. [CrossRef]

6. Sun, P.; Wu, H.; Bai, N.; Zhou, H.; Wang, R.; Feng, H.; Zhu, W.; Zhang, J.; Fang, J. Inactivation of Bacillus subtilis spores in water by a direct-current, cold atmospheric-pressure air plasma microjet. Plasma Process. Polym. 2012, 9, 157-164. [CrossRef]

7. Liu, F.; Sun, P.; Bai, N.; Tian, Y.; Zhou, H.; Wei, S.; Zhou, Y.; Zhang, J.; Zhu, W.; Becker, K.; et al. Inactivation of bacteria in an aqueous environment by a direct-current, cold-atmospheric-pressure air plasma microjet. Plasma Process. Polym. 2010, 7, 231-236. [CrossRef]

8. Puac, N.; Gherardi, M.; Shiratani, M. Plasma agriculture: A rapidly emerging field. Plasma Process. Polym. 2018, 15, 1700174. [CrossRef]

9. Li, Y.; Kang, M.H.; Uhm, H.S.; Lee, G.J.; Choi, E.H.; Han, I. Effects of atmospheric-pressure non-thermal bio-compatible plasma and plasma-activated nitric oxide water on cervical cancer cells. Sci. Rep. 2017, 7, 45781. [CrossRef]

10. Lee, G.J.; Kwon, Y.W.; Kim, Y.H.; Choi, E.H. Raman spectroscopic study of plasma-treated salmon DNA. Appl. Phys. Lett. 2013, 102, 021911.

11. Noh, H.; Kim, J.E.; Kim, J.Y.; Kim, S.H.; Han, I.; Lim, J.; Ki, S.H.; Choi, E.H.; Lee, G.J. Spore viability and cell wall integrity of Cordyceps pruinosa treated with an electric shock-free, atmospheric-pressure air plasma jet. Appl. Sci. 2019, 9, 3921. [CrossRef]

12. Ki, S.H.; Noh, H.; Ahn, G.R.; Kim, S.H.; Kaushik, N.K.; Choi, E.H.; Lee, G.J. Influence of nonthermal atmospheric plasma-activated water on the structural, optical, and biological properties of Aspergillus brasiliensis spores. Appl. Sci. 2020, 10, 6378. [CrossRef]

13. Lamichhane, P.; Paneru, R.; Nguyen, L.N.; Lim, J.S.; Bhartiya, P.; Adhikari, B.C.; Mumtaz, S.; Choi, E.H. Plasma-assisted nitrogen fixation in water with various metals. React. Chem. Eng. 2020, 5, 2053-2057. [CrossRef]

14. Lamichhane, P.; Veerana, M.; Lim, J.S.; Mumtaz, S.; Shrestha, B.; Kaushik, N.K.; Park, G.; Choi, E.H. Low-temperature plasmaassisted nitrogen fixation for corn plant growth and development. Int. J. Mol. Sci. 2021, 22, 5360. [CrossRef] [PubMed]

15. Kwon, H.W.; Kim, S.H. Pathological properties of Cryptococcus pseudolongus on the mycelia and fruit body of Lentinula edodes. Mycobiology 2021, 49, 173-182. [CrossRef] 
16. Maziarz, E.K.; Perfect, J.R. Cryptococcosis. Infect. Dis. Clin. N. Am. 2016, 30, 179-206. [CrossRef] [PubMed]

17. Gómez-Ramírez, A.; Cotrino, J.; Lambert, R.M.; González-Elipe, A.R. Efficient synthesis of ammonia from $\mathrm{N}_{2}$ and $\mathrm{H}_{2}$ alone in a ferroelectric packed-bed DBD reactor. Plasma Sources Sci. Technol. 2015, 24, 065011. [CrossRef]

18. Wang, Y.; Craven, M.; Yu, X.; Ding, J.; Bryant, P.; Huang, J.; Tu, X. Plasma-enhanced catalytic synthesis of ammonia over a $\mathrm{Ni} / \mathrm{Al}_{2} \mathrm{O}_{3}$ catalyst at near-room temperature: Insights into the importance of the catalyst surface on the reaction mechanism. ACS Catal. 2019, 9, 10780-10793. [CrossRef]

19. Jiang, H.; Shao, T.; Zhang, C.; Li, W.; Yan, P.; Che, X.; Schamiloglu, E. Experimental study of Q-V Lissajous figures in nanosecondpulse surface discharges. IEEE Trans. Dielectr. Electr. Insul. 2013, 20, 1101-1111. [CrossRef]

20. Kim, J.Y.; Lee, I.H.; Kim, D.; Kim, S.H.; Kwon, Y.W.; Han, G.H.; Cho, G.; Choi, E.H.; Lee, G.J. Effects of reactive oxygen species on the biological, structural, and optical properties of Cordyceps pruinosa spores. RSC Adv. 2016, 6, 30699-30709. [CrossRef]

21. Lee, G.J.; Sim, G.B.; Choi, E.H.; Kwon, Y.W.; Kim, J.Y.; Jang, S.; Kim, S.H. Optical and structural properties of plasma-treated Cordyceps bassiana spores as studied by circular dichroism, absorption, and fluorescence spectroscopy. J. Appl. Phys. 2015, 117, 023303. [CrossRef]

22. Atomic Spectra Database. Available online: https://www.nist.gov/pml/atomic-spectra-database (accessed on 1 February 2021).

23. Sarani, A.; Nikiforov, A.Y.; Leys, C. Atmospheric pressure plasma jet in $\mathrm{Ar}$ and $\mathrm{Ar} / \mathrm{H}_{2} \mathrm{O}$ mixtures: Optical emission spectroscopy and temperature measurements. Phys. Plasmas 2010, 17, 063504. [CrossRef]

24. Ershov, A.; Borysow, J. Dynamics of $\mathrm{OH} X^{2} \Pi(v=0)$ in high-energy atmospheric pressure electrical pulsed discharge. J. Phys. D Appl. Phys. 1995, 28, 68-74. [CrossRef]

25. Rahman, A.; Yalin, A.; Surla, V.; Stan, O.; Hoshimiya, K.; Yu, Z.; Littlefield, E.; Collins, G. Absolute UV and VUV emission in the 110-400 nm region from $13.56 \mathrm{MHz}$ driven hollow slot microplasmas operating in open air. Plasma Sources Sci. Technol. 2004, 13, 537-547. [CrossRef]

26. Ghimire, B.; Lamichhane, P.; Lim, J.S.; Min, B.; Paneru, R.; Weltmann, K.D.; Choi, E.H. An atmospheric pressure plasma jet operated by injecting natural air. Appl. Phys. Lett. 2018, 113, 194101. [CrossRef]

27. Lee, G.J.; Choi, M.A.; Kim, D.; Kim, J.Y.; Ghimire, B.; Choi, E.H.; Kim, S.H. Influence of plasma-generated reactive species on the plasmid DNA structure and plasmid-mediated transformation of Escherichia coli cells. J. Appl. Phys. 2017, 122, 103303. [CrossRef]

28. Giorgio, M.; Trinei, M.; Migliaccio, E.; Pelicci, P.G. Hydrogen peroxide: A metabolic by-product or a common mediator of ageing signals? Nat. Rev. Mol. Cell Biol. 2007, 8, 722-728. [CrossRef] [PubMed]

29. Farr, S.B.; Kogoma, T. Oxidative stress responses in Escherichia coli and Salmonella typhimurium. Microbiol. Mol. Biol. Rev. 1991, 55, 561-585. [CrossRef] [PubMed]

30. Bielski, B.H.J.; Cabelli, D.E.; Arudi, R.L.; Ross, A.B. Reactivity of $\mathrm{HO}_{2} / \mathrm{O}_{2}^{-}$radicals in aqueous solution. J. Phys. Chem. Ref. Data 1985, 14, 1041-1100. [CrossRef]

31. De Grey, A.D.N.J. $\mathrm{HO}_{2}^{\bullet}$ : The forgotten radical. DNA Cell Biol. 2002, 21, 251-257. [CrossRef]

32. Schmidt-Bleker, A.; Winter, J.; Bosel, A.; Reuter, S.; Weltmann, K.D. On the plasma chemistry of a cold atmospheric argon plasma jet with shielding gas device. Plasma Sources Sci. Technol. 2015, 25, 015005. [CrossRef]

33. Schmidt-Bleker, A.; Winter, J.; Iseni, S.; Dunnbier, M.; Weltmann, K.D.; Reuter, S. Reactive species output of a plasma jet with a shielding gas device-combination of FTIR absorption spectroscopy and gas phase modelling. J. Phys. D Appl. Phys. 2014, 47, 145201. [CrossRef]

34. Uhm, H.S. Generation of various radicals in nitrogen plasma and their behavior in media. Phys. Plasmas 2015, $22,123506$. [CrossRef]

35. Uhm, H.S.; Na, Y.H.; Lee, C.B.; Choi, E.H.; Cho, G. Dissociation and excitation coefficients of nitrogen molecules and radical generation in nitrogen plasma. Curr. Appl. Phys. 2014, 14, S162-S166. [CrossRef]

36. Lee, G.; Park, J. Reaction of zero-valent magnesium with water: Potential applications in environmental remediation. Geochim. Cosmochim. Acta 2013, 102, 162-174. [CrossRef]

37. Tsukahara, H.; Ishida, T.; Mayumi, M. Gas-phase oxidation of nitric oxide: Chemical kinetics and rate constant. Nitric Oxide 1999, 3, 191-198. [CrossRef]

38. Bibinov, N.; Knake, N.; Bahre, H.; Awakowicz, P.; Schulz-von der Gathen, V. Spectroscopic characterization of an atmospheric pressure $\mu$-jet plasma source. J. Phys. D Appl. Phys. 2011, 44, 345204. [CrossRef]

39. Deng, X.L.; Nikiforov, A.Y.; Vanraes, P.; Leys, C. Direct current plasma jet at atmospheric pressure operating in nitrogen and air. J. Appl. Phys. 2013, 113, 023305. [CrossRef]

40. Lukes, P.; Dolezalova, E.; Sisrova, I.; Clupek, M. Aqueous-phase chemistry and bactericidal effects from an air discharge plasma in contact with water: Evidence for the formation of peroxynitrite through a pseudo-second-order post-discharge reaction of $\mathrm{H}_{2} \mathrm{O}_{2}$ and $\mathrm{HNO}_{2}$. Plasma Sources Sci. Technol. 2014, 23, 015019. [CrossRef]

41. Van Gils, C.A.J.; Hofmann, S.; Boekema, B.K.H.L.; Brandenburg, R.; Bruggeman, P.J. Mechanisms of bacterial inactivation in the liquid phase induced by a remote RF cold atmospheric pressure plasma jet. J. Phys. D Appl. Phys. 2013, 46, 175203. [CrossRef]

42. Ignarro, L.J.; Fukuto, J.M.; Griscavage, J.M.; Rogers, N.E.; Byrns, R.E. Oxidation of nitric oxide in aqueous solution to nitrite but not nitrate: Comparison with enzymatically formed nitric oxide from L-arginine. Proc. Natl. Acad. Sci. USA 1993, 90, 8103-8107. [CrossRef]

43. Pires, M.; Rossi, M.J.; Ross, D.S. Kinetic and mechanistic aspects of the $\mathrm{NO}$ oxidation by $\mathrm{O}_{2}$ in aqueous phase. Int. J. Chem. Kinet. 1994, 26, 1207-1227. [CrossRef] 
44. Lamichhane, P.; Ghimire, B.; Mumtaz, S.; Paneru, R.; Ki, S.H.; Choi, E.H. Control of hydrogen peroxide production in plasmaactivated water by utilizing nitrification. J. Phys. D Appl. Phys. 2019, 52, 265206. [CrossRef]

45. Gaffney, J.S.; Marley, N.A.; Cunningham, M.M. Measurement of the absorption constants for nitrate in water between 270 and 335 nm. Environ. Sci. Technol. 1992, 26, 207-209. [CrossRef]

46. Lanoul, A.; Coleman, T.; Asher, S.A. UV resonance Raman spectroscopic detection of nitrate and nitrite in waste water treatment processes. Anal. Chem. 2002, 74, 1458-1461. [PubMed]

47. Tian, Y.; Ma, R.; Zhang, Q.; Feng, H.; Liang, Y.; Zhang, J.; Fang, J. Assessment of the physicochemical properties and biological effects of water activated by non-thermal plasma above and beneath the water surface. Plasma Process. Polym. 2015, 12, 439-449. [CrossRef]

48. Szabo, C.; Ohshima, H. DNA damage induced by peroxynitrite: Subsequent biological effects. Nitric Oxide 1997, 1, 373-385. [CrossRef]

49. Carey, D.M.; Korenowski, G.M. Measurement of the Raman spectrum of liquid water. J. Chem. Phys. 1998, 108, 2669-2675. [CrossRef]

50. Moskovits, M.; Michaelian, K.H. A reinvestigation of the Raman spectrum of water. J. Chem. Phys. 1978, 69, 2306-2311. [CrossRef]

51. Xu, M.; Larentzos, J.P.; Roshdy, M.; Criscenti, L.J.; Allen, H.C. Aqueous divalent metal-nitrate interactions: Hydration versus ion pairing. Phys. Chem. Chem. Phys. 2008, 10, 4793-4801. [CrossRef]

52. Fontana, M.D.; Mabrouk, K.B.; Kauffmann, T.H. Raman Spectroscopic Sensors for Inorganic Salts. In Spectroscopic Properties of Inorganic and Organometallic Compounds; Yarwood, J., Douthwaite, R., Duckett, S., Eds.; RSC Publishing: Cambridge, UK, 2013; Volume 44, pp. 40-67.

53. Koussinsa, F.; Bertin, F. Raman microspectrometric study of the dissolution layer of $\mathrm{M}_{\left(\mathrm{NO}_{3}\right)_{2} \cdot \mathrm{nH}} \mathrm{H}_{2}$ crystals $(\mathrm{M}=\mathrm{Mg}$, Ca, $\mathrm{Zn}$ and $\mathrm{Cd}$ ) in their undersaturated aqueous solutions. J. Raman Spectrosc. 1991, 22, 169-176. [CrossRef]

54. Bowman, S.M.; Free, S.J. The structure and synthesis of the fungal cell wall. BioEssays 2006, 28, 799-808. [CrossRef] [PubMed]

55. Williams, L.E.; Miller, A.J. Transporters responsible for the uptake and partitioning of nitrogenous solutes. Annu. Rev. Plant Physiol. Plant Mol. Biol. 2001, 52, 659-688. [CrossRef] [PubMed] 